\section{Epidemiology and Psychiatric}

Sciences

\section{cambridge.org/eps}

\section{Special Article}

Cite this article: Giacco D (2020). Identifying the critical time points for mental health of asylum seekers and refugees in high-income countries. Epidemiology and Psychiatric Sciences 29, e61, 1-10. https://doi.org/10.1017/ S204579601900057X

Received: 15 April 2019

Revised: 20 August 2019

Accepted: 31 August 2019

\section{Key words:}

Epidemiology; mental health; minority issues and cross-cultural psychiatry; risk factors

Author for correspondence:

Domenico Giacco,

E-mail: d.giacco@qmul.ac.uk (c) The Author(s) 2019. This is an Open Access article, distributed under the terms of the Creative Commons Attribution licence (http:// creativecommons.org/licenses/by/4.0/), which permits unrestricted re-use, distribution, and reproduction in any medium, provided the original work is properly cited.

\title{
Identifying the critical time points for mental health of asylum seekers and refugees in high-income countries
}

\section{Domenico Giacco (10)}

Unit for Social and Community Psychiatry, Queen Mary University of London (WHO Collaborating Centre for Mental Health Service Development), Newham Centre for Mental Health, E13 8SP, London, UK

\begin{abstract}
Aims. High heterogeneity was found in the prevalence rates of mental disorders in adult asylum seekers and refugees in high-income countries. This may be related to different problems. Among them, there is a changing exposure to risk and protective factors for mental health at different phases of these people's life before migration, and during the migratory journey and resettlement. This study aimed at identifying and distinguishing time points in which distinct risk and protective factors for the mental health of asylum seekers and refugees may occur. Methods. Systematic review and narrative synthesis. A systematic search was carried out for the period January 2017-August 2019, given the existence of systematic reviews of the evidence up to January 2017.

Results. Two hundred and fifty-two studies were identified with our search and 31 studies were included. The critical time points identified are: (a) before the travel; (b) during the travel; (c) at initial settlement in the host country; (d) when attempting to integrate in the host country; (e) when the immigration status is challenged or revoked. Some factors such as sense of belonging in the host country can be risk factors or protective factors depending on the time point.

Conclusions. These five critical time points can guide the development and selection of well-timed preventive and treatment interventions. They could also be used to stratify samples in epidemiological studies and meta-analyses. At present, we know much more on risk factors than on protective factors. Knowing more about protective factors may inform the development of interventions to foster them.
\end{abstract}

\section{Introduction}

The recent refugee crisis and migratory waves have been the focus of much political attention in high-income countries (Gianfreda, 2018). A major area of debate has been how to address the health needs of the high numbers of new individuals coming into a country in a short timeframe (Priebe et al., 2016).

Refugees' mental health needs have been a particular concern. Specifically, the factors which may lead to refugees' migration, i.e. exposure to political persecution and war (UNHCR, 2019) can also predispose them to mental disorders (WHO, 2018).

This gave impetus to the research in this field and a number of studies have assessed prevalence rates in different groups of asylum seekers and refugees and for different mental disorders (e.g. Priebe et al., 2016; Turrini et al., 2017; Giacco et al., 2018).

However, when assessing prevalence rates of mental disorders in these groups, a number of problems may arise, which are reflected by a high heterogeneity in prevalence rates across studies (Priebe et al., 2016; Giacco and Priebe, 2018; Giacco et al., 2018). These problems are usually summarised as follows:

(a) There are pragmatic challenges in carrying out epidemiological studies in these groups, such as language barriers, lack of validity of research tools across different cultures (Lewis-Fernandez and Aggarwal, 2013; Brisset et al., 2014; Giacco et al., 2014) and difficulties in accessing some individuals or groups (Enticott et al., 2017); these challenges may lead to bias within studies and methodological artefacts;

(b) There are differences among individuals and groups of asylum seekers and refugees based on different personal backgrounds, as well as differing social situations in home countries and host countries (Priebe et al., 2016; Giacco et al., 2018).

The challenges in achieving representative samples can be overcome to some extent by technical safeguards such as using well-trained interpreters or same language interviewers, adopting culturally validated instruments and using carefully designed sampling techniques. 
The individual or group differences across asylum seekers and refugees are, instead, true, not influenced by methodology, and, as such, generate unavoidable heterogeneity across studies.

However, there is a third type of problems, which have received less attention from the epidemiological research so far. The statuses of asylum seekers and refugees are determined by legal frameworks and procedures and are transitory in nature. They do not identify stable categories, with which rates of mental disorders can be reliably associated.

These changing statuses can be summarised as follows. All refugees are initially classed as asylum seekers (UNHCR, 2019). The process of obtaining asylum and refugee status can last a long time. During this time, they have the right to remain in the host country but are uncertain as to whether their application will be approved. If the asylum application is not approved, they can leave that country (and move to another country), appeal or become irregular migrants. The refugee status can also be revoked ('cessation of their refugee status') (Kapferer, 2003) once a host country court rules that the causes of political persecution or lack of safety (e.g. wars, political regimes, etc.) have ceased in the refugees' home countries.

So far, refugees, asylum seekers and people who do not have a recognised immigration status in a new country have usually been pooled together in research studies and meta-analyses. This may lead us to ignore differences in stressors which may have a considerable impact on a person's mental health.

The usual stratification of risk factors for mental health is based on a simplified framework in which refugees encounter pre-, peri- and post-migration factors (Priebe et al., 2016; Giacco et al., 2018). This has not influenced sampling for epidemiological studies as these studies are usually carried out in the host countries (i.e. post-migration).

\section{Aims}

This study aimed to carry out a systematic review of the evidence on risk and protective factors for the mental health of asylum seekers, refugees and in general of people who have been forcibly displaced from their countries. We then sought to classify these factors according to different stages in the life before migration, migration journey and resettlement of these people, with a particular attention to the increasing evidence on post-migration factors (Priebe et al., 2016; Miller and Rasmussen, 2017).

\section{Methods}

\section{Design}

This study is a systematic review with a narrative synthesis of the findings.

Previous literature reviews appraised the evidence on risk and protective factors for refugees' and asylum seekers' mental health until January 2017 (Priebe et al., 2016; Giacco et al., 2018).

A systematic search of the evidence was carried out from January 2017 to August 2019 in order to provide the most updated findings. It used similar inclusion criteria but a simplified search strategy and did not include grey literature. This is because our previous reviews were also interested in identifying interventions and good practices, which are often found in other types of documents and sources. The current study, instead, was specifically focused on risk and protective factors for mental health, for which we are aware that an adequate amount of evidence is available in the scientific peer-reviewed literature. Focusing on peer-reviewed literature also ensured that sufficient quality standards were adhered to by all included papers.

\section{Paper identification and selection}

The search words used were the following: ('refugee' OR 'asylum seeker' OR 'irregular migrant' OR 'undocumented migrant') AND ('mental health') AND ('risk factors' OR 'correlates'). EMBASE, PsychINFO and OVID Medline databases were searched.

Papers were included if: (a) at least $50 \%$ of the research participants were refugees and/or asylum seekers; (b) they assessed risk or protective factors for mental disorders; (c) they focused on adult populations (18 or older years of age); (d) they reported on studies carried out in high-income countries (according to the World Bank Classification); (e) they reported on primary research or were literature reviews, excluding opinion pieces; (f) they were published in full articles or full reports in scientific journals, excluding grey literature and conference presentations.

Papers were excluded if they focused only on aspects other than risk and protective factors for mental disorders, e.g. interventions, prevalence rates without correlates, individuals' experience of care or barriers to access care. Qualitative studies which described patients' or clinicians' views about which were potential risks or potential factors for mental health were also excluded. They were deemed as 'non-focusing on risk and protective factors for mental health' given that they failed to demonstrate the actual association of those factors with mental health, only suggesting that this may be.

\section{Procedures and analysis}

From each paper identified, risk and protective factors were captured and summarised in an excel extraction table.

The risk and protective factors identified from different studies were initially grouped together according to when they occurred, based on the usual framework (pre-, peri- and post-migration).

The analysis then continued with the aim of re-grouping risk and protective factors in more specific and discrete time points which generated the final time points described in the Results section.

\section{Results}

Our search identified 252 papers in the period January 2017August 2019. After removal of duplicates and screening according to inclusion criteria, 31 papers were included, i.e. 28 papers reporting on primary research and three literature reviews.

The PRISMA diagram can be found in Fig. 1.

The main characteristics of the included studies are synthesised in Table 1.

Five time points were identified, in which all the risk and protective factors identified can be categorised. These time points are: (a) before travel; (b) during travel; (c) initial settlement in the host country; (d) integration in the host country; (e) challenges to or revocation of the immigration status.

A summary of risk and protective factors at all of these time points can be found in Fig. 2 .

These different time points can all be experienced by individuals who are forced to migrate from their countries. However, this is not necessarily the case for all of these individuals. For example, some of them may have their asylum applications 


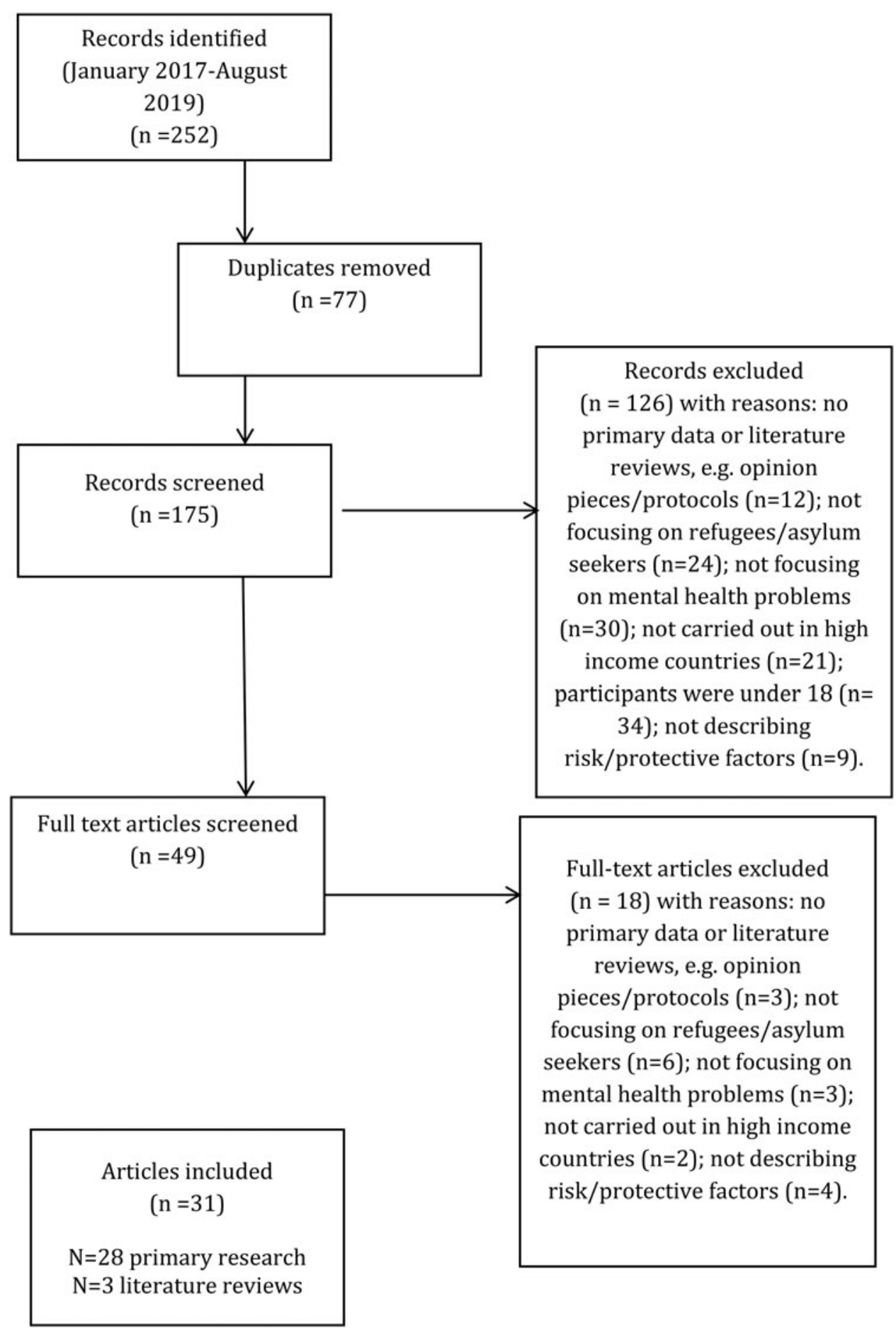

Fig. 1. PRISMA flow diagram.

rejected and never reach the status of a refugee. Others may integrate successfully and, hence, remain in the host country as naturalised citizens without their residence status being challenged.

\section{Before travel}

Exposure to potentially traumatic events (Chen et al., 2017a; Myhrvold and Småstuen, 2017; Giacco et al., 2018; Hynie, 2018; Kartal et al., 2018; Park et al., 2018), violent events witnessed or experienced (Ben Fahrat et al., 2018; Kaltenbach et al., 2018, Schweitzer et al., 2018; Rees et al., 2019) and particularly being subjected to torture (Nickerson et al., 2017; Le et al., 2018; Song et al., 2018) have all been linked to high likelihood of developing post-traumatic stress disorder and other forms of psychological distress. This is more likely if the experience of torture is accompanied by intense emotions of anger, fear and perceived uncontrollability (Le et al., 2018). The risk of developing a mental disorder also increases if a person is exposed to multiple potentially 
Table 1. Details of the included studies $(N=31)$

\begin{tabular}{|c|c|c|c|c|}
\hline Authors & Country(-ies) & Study design & $\begin{array}{l}N \text { of refugees/asylum seekers } \\
\text { included }\end{array}$ & $\begin{array}{l}\text { Risk/protective factors towards mental disorders } \\
\text { identified }\end{array}$ \\
\hline $\begin{array}{l}\text { Anderson et al. } \\
(2017)\end{array}$ & $\begin{array}{l}\text { International } \\
\text { literature }\end{array}$ & $\begin{array}{l}\text { Systematic review } \\
\text { and meta-analysis }\end{array}$ & $\mathrm{N} / \mathrm{A}$ & $\begin{array}{l}\text { Risk factors: low social support, minority } \\
\text { ethnicity, low socioeconomic status, lack of } \\
\text { proficiency in host country language and } \\
\text { refugee/asylum-seeking status }\end{array}$ \\
\hline \multirow[t]{2}{*}{$\begin{array}{l}\text { Beiser and Hou } \\
(2017)\end{array}$} & \multirow[t]{2}{*}{ Canada } & \multirow[t]{2}{*}{$\begin{array}{l}\text { Cross-sectional } \\
\text { survey }\end{array}$} & \multirow[t]{2}{*}{651 refugees } & $\begin{array}{l}\text { Risk factors: affiliative feelings towards the } \\
\text { home country. Perceived discrimination among } \\
\text { men, but not women }\end{array}$ \\
\hline & & & & $\begin{array}{l}\text { Protective factors: a sense of belonging to host } \\
\text { country. Bridging social networks, particularly } \\
\text { for women }\end{array}$ \\
\hline $\begin{array}{l}\text { Ben Fahrat } \\
\text { et al. (2018) }\end{array}$ & Greece & $\begin{array}{l}\text { Cross-sectional } \\
\text { survey }\end{array}$ & 1293 refugees & $\begin{array}{l}\text { Risk factor: violent events before, during and } \\
\text { post-migration. Uncertainty about asylum } \\
\text { application }\end{array}$ \\
\hline \multirow{2}{*}{$\begin{array}{l}\text { Chen et al. } \\
(2017 a)\end{array}$} & \multirow[t]{2}{*}{ Australia } & \multirow{2}{*}{$\begin{array}{l}\text { Cross-sectional } \\
\text { survey }\end{array}$} & 2399 refugees & \multirow{2}{*}{$\begin{array}{l}\text { Risk factors: both pre-migration potentially } \\
\text { traumatic events and post-migration stressors } \\
\text { were positively associated with PTSD and severe } \\
\text { mental illness. Loneliness and the number of } \\
\text { social integration stressors increased the risk of } \\
\text { mental health problems particularly if there } \\
\text { were pre-migration traumatic events }\end{array}$} \\
\hline & & & $\begin{array}{l}762 \text { had PTSD and } 394 \text { had } \\
\text { other mental illness }\end{array}$ & \\
\hline $\begin{array}{l}\text { Chen et al. } \\
(2017 b)\end{array}$ & Australia & $\begin{array}{l}\text { Cross-sectional } \\
\text { survey }\end{array}$ & 2399 refugees & $\begin{array}{l}\text { Protective factors: less financial hardship } \\
\text { (economic integration dimension), better } \\
\text { English proficiency and self-sufficiency } \\
\text { (acculturation dimension), having the capacity } \\
\text { to communicate with locals, having friends from } \\
\text { different ethnic/religious groups and attending a } \\
\text { place of worship weekly or more often (social } \\
\text { capital dimension) and feeling welcomed and } \\
\text { having a strong sense of belonging in the host } \\
\text { country (self-identity dimension) }\end{array}$ \\
\hline \multirow{3}{*}{$\begin{array}{l}\text { Dennis et al. } \\
2017\end{array}$} & \multirow[t]{3}{*}{ Canada } & \multirow{3}{*}{$\begin{array}{l}\text { Cross-sectional } \\
\text { survey }\end{array}$} & 449 & \multirow{2}{*}{$\begin{array}{l}\text { Risk factors: experiencing abuse, pain } \\
\text { post-birth, worried about family members left } \\
\text { behind, had food insecurity and had reduced } \\
\text { access to healthcare }\end{array}$} \\
\hline & & & \multirow[t]{2}{*}{$\begin{array}{l}\text { Refugee women who had } \\
\text { recently given birth ( } 2-16 \text { weeks } \\
\text { before) }\end{array}$} & \\
\hline & & & & $\begin{array}{l}\text { Protective factors: higher levels of social support } \\
\text { and feeling they belonged to a community }\end{array}$ \\
\hline $\begin{array}{l}\text { Euteneuer and } \\
\text { Schäfer (2018) }\end{array}$ & Germany & $\begin{array}{l}\text { Cross-sectional } \\
\text { online survey }\end{array}$ & 164 male refugees & $\begin{array}{l}\text { Risk factors: downward mobility in subjectively } \\
\text { perceived social status is associated with } \\
\text { depression }\end{array}$ \\
\hline $\begin{array}{l}\text { Finnvold and } \\
\text { Ugreninov } \\
\text { (2018) }\end{array}$ & Norway & $\begin{array}{l}\text { Analysis of register } \\
\text { data }\end{array}$ & 30871 refugees & $\begin{array}{l}\text { Protective factors: ethnic density effect. } \\
\text { Refugees living in clusters tend to have less use } \\
\text { of mental healthcare services (proxy for mental } \\
\text { health problems) }\end{array}$ \\
\hline Hynie, 2018 & $\begin{array}{l}\text { International } \\
\text { literature }\end{array}$ & $\begin{array}{l}\text { Narrative literature } \\
\text { review }\end{array}$ & $\mathrm{N} / \mathrm{A}$ & $\begin{array}{l}\text { Risk factors: exposure to violence and trauma, } \\
\text { particularly repeated exposures and extreme } \\
\text { violence such as torture, an increased length of } \\
\text { displacement }\end{array}$ \\
\hline $\begin{array}{l}\text { Hvidtfeldt et al. } \\
\text { (2019) }\end{array}$ & Denmark & $\begin{array}{l}\text { Analysis of register } \\
\text { data }\end{array}$ & 46104 refugees & $\begin{array}{l}\text { Risk factors: long asylum-decision waiting } \\
\text { periods were associated with an increased risk } \\
\text { of psychiatric disorders }\end{array}$ \\
\hline $\begin{array}{l}\text { Kaltenbach } \\
\text { et al. (2018) }\end{array}$ & Germany & Cohort study & 57 refugees - 1 year follow-up & $\begin{array}{l}\text { Risk factors: a higher number of traumatic } \\
\text { experiences was related to a greater intensity of } \\
\text { PTSD symptoms. In addition, post-migrational } \\
\text { stressors were associated with a worsening of } \\
\text { PTSD symptoms over the course of the year. } \\
\text { Emotional distress was associated with current } \\
\text { negative life events, unemployment and } \\
\text { frequent visits to physicians }\end{array}$ \\
\hline $\begin{array}{l}\text { Kartal et al. } \\
(2018)\end{array}$ & $\begin{array}{l}\text { Australia and } \\
\text { Austria }\end{array}$ & $\begin{array}{l}\text { Cross-sectional } \\
\text { survey }\end{array}$ & 138 refugees & $\begin{array}{l}\text { Risk factors: exposure to trauma and } \\
\text { acculturative stress mediating the effect of } \\
\text { traumatic exposure }\end{array}$ \\
\hline
\end{tabular}


Table 1. (Continued.)

\begin{tabular}{|c|c|c|c|c|}
\hline Authors & Country(-ies) & Study design & $\begin{array}{l}N \text { of refugees/asylum seekers } \\
\text { included }\end{array}$ & $\begin{array}{l}\text { Risk/protective factors towards mental disorders } \\
\text { identified }\end{array}$ \\
\hline $\begin{array}{l}\text { Kashyap et al. } \\
\text { (2019) }\end{array}$ & USA & Cohort study & $\begin{array}{l}323 \text { refugees who are torture } \\
\text { survivors }\end{array}$ & $\begin{array}{l}\text { Protective factors (after } 6 \text { months of treatment) } \\
\text { female gender, change to a more secure visa } \\
\text { status, accessing more social services, not } \\
\text { reporting chronic pain, stable housing and } \\
\text { employment }\end{array}$ \\
\hline Le et al. (2018) & Switzerland & $\begin{array}{l}\text { Cross-sectional } \\
\text { survey }\end{array}$ & $\begin{array}{l}108 \text { refugees and asylum } \\
\text { seekers having experienced or } \\
\text { witnessed torture }\end{array}$ & $\begin{array}{l}\text { Risk factors: perceived uncontrollability and } \\
\text { distress during torture might be significant risk } \\
\text { factors for current mental health of torture } \\
\text { survivors }\end{array}$ \\
\hline \multirow[t]{2}{*}{ Lee et al. (2017) } & South Korea & Literature review & $\mathrm{N} / \mathrm{A}$ & $\begin{array}{l}\text { Risk factors: traumatic experiences, longer stay } \\
\text { periods in third country, forced repatriation, } \\
\text { acculturative stress, low income, older age, poor } \\
\text { physical health }\end{array}$ \\
\hline & & & & $\begin{array}{l}\text { Protective factors: educational level, social } \\
\text { support, family relationship quality and } \\
\text { resilience }\end{array}$ \\
\hline $\begin{array}{l}\text { Leiler et al. } \\
\text { (2019) }\end{array}$ & Sweden & $\begin{array}{l}\text { Cross-sectional } \\
\text { survey }\end{array}$ & $\begin{array}{l}510 \text { refugees, among them } 367 \\
\text { asylum seekers }\end{array}$ & Risk factors: waiting for decision on asylum \\
\hline $\begin{array}{l}\text { Miller et al. } \\
(2018)\end{array}$ & USA & $\begin{array}{l}\text { Cross-sectional } \\
\text { survey }\end{array}$ & 165 refugees & Risk factors: separation from family members \\
\hline $\begin{array}{l}\text { Müller et al. } \\
(2018)\end{array}$ & Germany & $\begin{array}{l}\text { Cross-sectional } \\
\text { survey }\end{array}$ & 620 migrants, 79 asylum seekers & $\begin{array}{l}\text { Risk factors: asylum seeking (as opposed to } \\
\text { having achieved permanent residence status) }\end{array}$ \\
\hline $\begin{array}{l}\text { Mulugeta et al. } \\
\text { (2019) }\end{array}$ & USA & $\begin{array}{l}\text { Analysis of register } \\
\text { data }\end{array}$ & 1055 refugees & $\begin{array}{l}\text { Risk factors: female gender, longer } \\
\text { displacement }\end{array}$ \\
\hline $\begin{array}{l}\text { Myhrvold and } \\
\text { Småstuen } \\
\text { (2017) }\end{array}$ & Norway & $\begin{array}{l}\text { Cross-sectional } \\
\text { survey }\end{array}$ & $\begin{array}{l}90 \text { undocumented migrants, } 48 \\
\text { migrating because of war or } \\
\text { persecution }\end{array}$ & $\begin{array}{l}\text { Risk factors: having experienced abuse. Having } \\
\text { family and work had no positive effect on } \\
\text { mental health }\end{array}$ \\
\hline $\begin{array}{l}\text { Nickerson et al., } \\
\text { (2017) }\end{array}$ & Switzerland & $\begin{array}{l}\text { Cross-sectional } \\
\text { survey }\end{array}$ & 134 refugees & $\begin{array}{l}\text { Risk factors: female gender, age, time in } \\
\text { Switzerland, trauma exposure and } \\
\text { post-migration stress }\end{array}$ \\
\hline $\begin{array}{l}\text { Nosè et al. } \\
(2018)\end{array}$ & Italy & $\begin{array}{l}\text { Cross-sectional } \\
\text { survey }\end{array}$ & $\begin{array}{l}109 \text { male asylum seekers or } \\
\text { refugees }\end{array}$ & $\begin{array}{l}\text { Risk factors: time after departure, length of stay } \\
\text { in the host country and number of traumatic } \\
\text { events }\end{array}$ \\
\hline $\begin{array}{l}\text { Park et al. } \\
\text { (2018) }\end{array}$ & South Korea & $\begin{array}{l}\text { Cross-sectional } \\
\text { survey }\end{array}$ & 109 refugees & $\begin{array}{l}\text { Risk factors: early traumatic experiences were } \\
\text { positively associated with depressive symptoms }\end{array}$ \\
\hline \multirow[t]{2}{*}{$\begin{array}{l}\text { Poole et al. } \\
\text { (2018) }\end{array}$} & Greece & $\begin{array}{l}\text { Cross-sectional } \\
\text { survey }\end{array}$ & $\begin{array}{l}135 \text { asylum seekers and } \\
\text { refugees in a refugee camp }\end{array}$ & $\begin{array}{l}\text { Risk factors: female sex, number of children and } \\
\text { increased time in the asylum process in Greece } \\
\text { were significant risk factors for major depressive } \\
\text { disorder }\end{array}$ \\
\hline & & & & Protective factors: being married \\
\hline $\begin{array}{l}\text { Rees et al. } \\
\text { (2019) }\end{array}$ & Australia & $\begin{array}{l}\text { Cross-sectional } \\
\text { survey }\end{array}$ & $\begin{array}{l}1335 \text { women accessing public } \\
\text { antenatal clinics ( } 685 \text { from } \\
\text { conflict-affected backgrounds) }\end{array}$ & $\begin{array}{l}\text { Refugees were more likely than host country } \\
\text { natives to present with major depressive } \\
\text { disorder and to have been exposed to } \\
\text { potentially traumatic events, intimate partner } \\
\text { violence. They had less social support and more } \\
\text { financial stressors }\end{array}$ \\
\hline $\begin{array}{l}\text { Sangalang et al. } \\
\text { (2018) }\end{array}$ & USA & $\begin{array}{l}\text { Cross-sectional } \\
\text { survey }\end{array}$ & $\begin{array}{l}3257 \text { immigrants, of whom } 1620 \\
\text { are refugees }\end{array}$ & $\begin{array}{l}\text { Risk factors: pre-migration potentially traumatic } \\
\text { events, discrimination, acculturative stress and } \\
\text { family conflict }\end{array}$ \\
\hline $\begin{array}{l}\text { Schick et al. } \\
(2018)\end{array}$ & Switzerland & Cohort study & $\begin{array}{l}71 \text { asylum seekers/refugees who } \\
\text { have been in psychiatric } \\
\text { treatment - } 3 \text { year follow-up }\end{array}$ & $\begin{array}{l}\text { Improvement in post-migration difficulties, } \\
\text { particularly visa status, was associated with } \\
\text { PTSD, depression and anxiety symptom } \\
\text { improvement }\end{array}$ \\
\hline $\begin{array}{l}\text { Schweitzer et al. } \\
\text { (2018) }\end{array}$ & & $\begin{array}{l}\text { Cross-sectional } \\
\text { survey }\end{array}$ & 104 female refugees & $\begin{array}{l}\text { Risk factors: higher numbers of trauma events } \\
\text { and post-migration living difficulties, having } \\
\text { children, age }\end{array}$ \\
\hline
\end{tabular}


Table 1. (Continued.)

\begin{tabular}{|c|c|c|c|c|}
\hline Authors & Country(-ies) & Study design & $\begin{array}{l}N \text { of refugees/asylum seekers } \\
\text { included }\end{array}$ & $\begin{array}{l}\text { Risk/protective factors towards mental disorders } \\
\text { identified }\end{array}$ \\
\hline $\begin{array}{l}\text { Song et al. } \\
(2018)\end{array}$ & USA & $\begin{array}{l}\text { Cross-sectional } \\
\text { survey }\end{array}$ & $\begin{array}{l}278 \text { refugees and asylum } \\
\text { seekers exposed to torture }\end{array}$ & $\begin{array}{l}\text { Risk factors: female sex, older age, cumulative } \\
\text { exposure to multiple torture types, unstable } \\
\text { housing and time spent in the USA before } \\
\text { presenting for services }\end{array}$ \\
\hline $\begin{array}{l}\text { Tinghög et al. } \\
\text { (2017) }\end{array}$ & Sweden & $\begin{array}{l}\text { Cross-sectional } \\
\text { survey }\end{array}$ & 1215 refugees & $\begin{array}{l}\text { Risk factors: potentially traumatic events, } \\
\text { especially being exposed to interpersonal } \\
\text { violence, and post-migration stress (composite } \\
\text { measure including perceived discrimination, } \\
\text { lack of host country-specific competencies, } \\
\text { economic strain, loss of home country, home } \\
\text { country and family concerns, social strains and } \\
\text { family conflicts) }\end{array}$ \\
\hline \multirow{2}{*}{$\begin{array}{l}\text { Yang and } \\
\text { Mutchler (2019) }\end{array}$} & \multirow[t]{2}{*}{ USA } & \multirow{2}{*}{$\begin{array}{l}\text { Cross-sectional } \\
\text { survey }\end{array}$} & \multirow{2}{*}{$\begin{array}{l}127 \text { refugees older than } 55 \\
\text { years. }\end{array}$} & Risk factors: self-reported poor health \\
\hline & & & & $\begin{array}{l}\text { Protective factors: larger household size and } \\
\text { older age of arrival into the USA }\end{array}$ \\
\hline
\end{tabular}

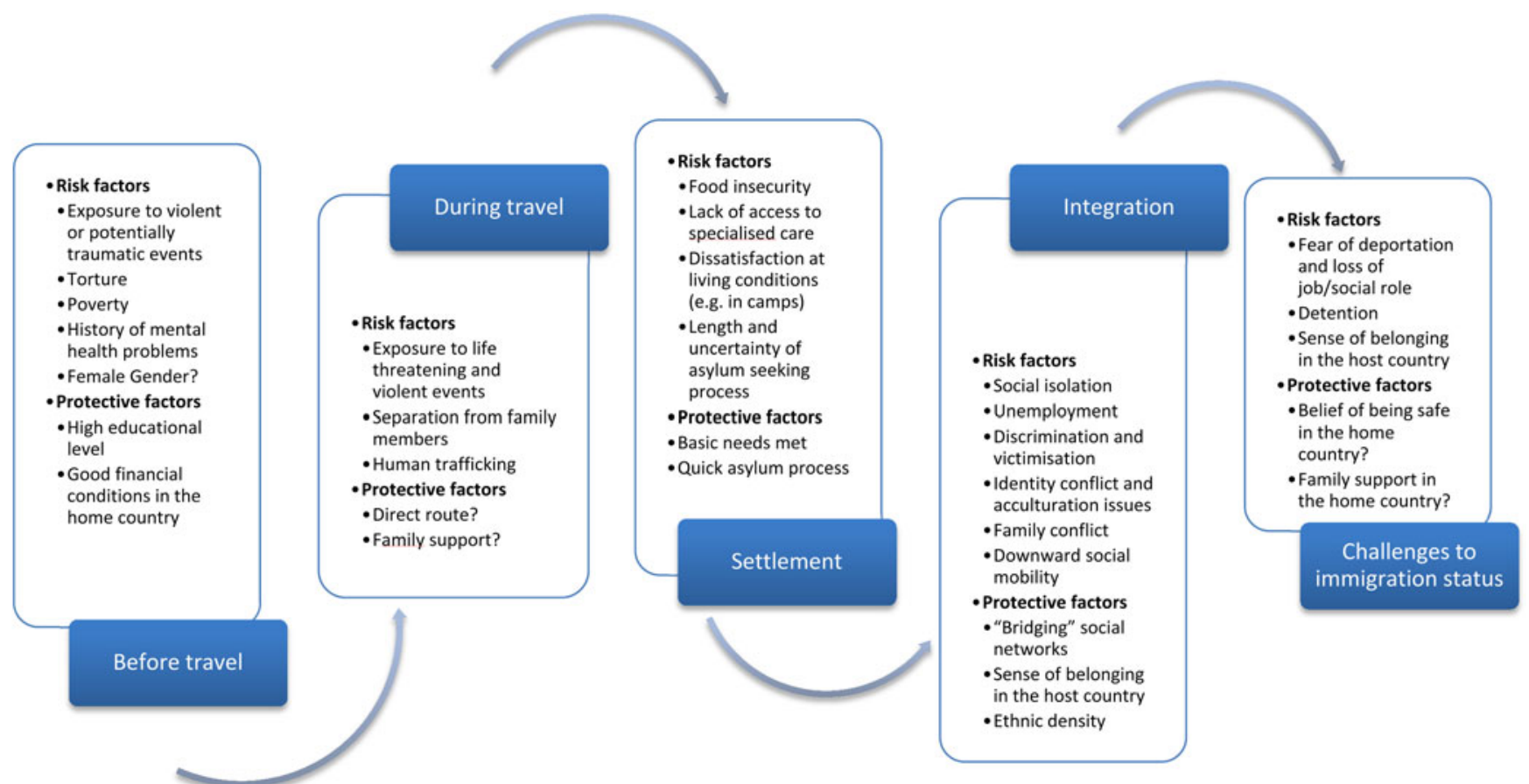

Fig. 2. Critical time points for the mental health of asylum seekers and refugees and risk and protective factors at play.

traumatic events and/or if post-migration adversities occur in addition to traumatic events before migration (Chen et al., 2017a; Lee et al., 2017; Nickerson et al., 2017; Tinghög et al., 2017; Giacco et al., 2018; Kartal et al., 2018; Nosè et al., 2018; Sangalang et al., 2018; Schweitzer et al., 2018; Song et al., 2018).

As well as traumatic events, exposure to economic hardship and social deprivation in home countries and a history of mental health problems before migration can predict mental disorders after settlement in host countries (Anderson et al., 2017; Giacco and Priebe, 2018).

On the other hand, having experienced good financial conditions and having attained a higher level of education in the home country are associated with reduced rates of mental disorders after migration (Lee et al., 2017; WHO, 2018).
Some studies have found that female gender is associated with a higher likelihood of presenting clinically significant mental health symptoms in asylum seekers and refugees (Poole et al., 2018; Song et al., 2018; Mulugeta et al., 2019). However, most studies did not identify differences across genders (see Table 1).

\section{During travel}

Refugees travel through dangerous land routes or via sea and can be exposed to violent events or abuse during their journey. Exposure to violent events during migration (Ben Fahrat et al., 2018; Poole et al., 2018) and to human trafficking (Ottosova et al., 2016; WHO, 2018) have been linked with poor mental health after resettlement. Separation from family members as 
part of the migration or during the migration (Miller et al., 2018) also has been found to have negative consequences on mental health.

There are no studies which have explored protective factors during migration. However, it is likely that travelling through less dangerous or more direct routes and having the support of family members or trusted friends during the travel is associated with less stress and impact on mental health.

\section{Settlement in a host country}

The risk factors encountered in the first period after settlement in a host country are related to food insecurity, lack of accommodation (Dennis et al., 2017; Song et al., 2018) and dissatisfaction with accommodation, particularly in refugee camps (Poole et al., 2018). A longer duration of the asylum seeking process and lack of information can generate prolonged stress and uncertainty which was found to be associated with clinically relevant psychological symptoms (Ben Fahrat et al., 2018; Poole et al., 2018).

Better conditions of settlement, access to health care (Dennis et al., 2017) and a prompter and/or smoother process for obtaining a residence status can have a positive impact on the mental health of refugees (Müller et al., 2018; Kashyap et al., 2019). The uncertainty related to asylum decisions is a factor which has been found to be consistently associated with poor mental health in a number of studies (Ben Fahrat et al., 2018; Leiler et al., 2019; Hvidtfeldt et al., 2019).

\section{Integration in a host country}

Prevalence studies show higher rates of mental disorders (particularly anxiety and depressive disorders) in long-term resettled refugees (at least 5 years) than in those at first resettlement (Bogic et al., 2015). Recent studies have also shown that an increased length of displacement can be associated with an increased likelihood of experiencing mental disorders (Hynie, 2018; Nosé et al., 2018; Mulugeta et al., 2019).

During the process of integration in the host country, risk factors for mental health can be social isolation (Anderson et al., 2017; Beiser and Hou, 2017; Chen et al., 2017a; Lee et al., 2017; Hynie, 2018; Schweitzer et al., 2018), unemployment (Kaltenbach et al., 2018), discrimination and victimisation (Sangalang et al., 2018), struggles related to their cultural identity and acculturation issues (Chen et al., 2017b; Lee et al., 2017) and downward social mobility (Euteneuer and Schafer, 2018).

A protective factor for mental health is having 'bridging social networks' (Chen et al., 2017b; Beiser and Hou, 2017), i.e. social networks including people from different ethnic groups. Developing a sense of belonging in the host country was also found to be associated with reduced likelihood of mental disorders (Chen et al., 2017b; Myhrvold and Småusten, 2017; Beiser and Hou, 2017) and so were positive changes in post-migration living arrangements (Shick et al., 2018). In particular, achieving a visa or resident status was associated with better response to treatment (Schick et al., 2018). Findings also suggest that refugees living in areas where there is a high number of people from their own ethnic group, i.e. a high 'ethnic density' may be less likely to use mental health services and hence less likely to present severe mental health needs (Finnvold and Ugreninov, 2018). In accordance with this, a larger household size was found to be a protective factor for mental health (Yang and Mutchler, 2019).

\section{Immigration status challenged or revoked}

At this time point, threats of deportation, detention in immigration centres and losing jobs or accommodation are recognised risk factors for psychological distress and diagnosable mental disorders (Priebe et al., 2016; Kashyap et al., 2019). A sense of belonging in the host country, which is a protective factor during integration, can become a risk factor if the immigration status is challenged (Lee et al., 2017).

No studies have assessed protective factors when immigration status is challenged or revoked. It might be expected that a sense of being safe in the home country, having a family or a social network there and maintaining a strong sense of belonging to the home country may be protective against psychological distress (whilst 'affiliative feelings towards the home country' can be a risk factor for mental health during the process of integration in the host country, as found in Beiser and Hou, 2017).

\section{Discussion}

\section{Main findings}

This review has identified five time points at different stages of the migration process of asylum seekers and refugees in which different risk and protective factors may occur. The time points identified go beyond the usual and simplified distinction of pre-migration, peri-migration and post-migration risk factors and constitute a more comprehensive categorisation.

\section{Implications}

The risk and protective factors identified have all been variably described in previous studies (Lindencrona et al., 2008; Steel et al., 2009; Bogic et al., 2012; Bogic et al., 2015). This study adds a novel categorisation with five distinct time points in which risk and protective factors can be encountered by refugees after migration. Despite the increased complexity of this categorisation, it may have a number of advantages as a framework for research, psychosocial assessment and selection of interventions.

First, this more comprehensive categorisation may help in interpreting the heterogeneity of prevalence studies (Bogic et al., 2015; WHO, 2018). It can provide a useful way of stratifying research participants in more homogeneous groups with regards to risk and protective factors for their mental health, and these groups may show more similar prevalence rates of mental disorders.

Second, the risk and protective factors identified can be a target of interventions aiming to address or foster them in prevention and treatment programmes specifically provided at different time points.

Third, it is important to observe that some factors may act as either risk or protective factors depending on the different time points. For example, sense of belonging in the host country is a protective factor during integration (Chen et al., 2017b; Myhrvold and Småusten, 2017; Beiser and Hou, 2017), but a risk factor in case of immigration status being challenged or revoked (Geraci (2011) and Lee et al., 2017). Similarly, affiliative feelings towards the home country can be a source of anxiety during migration, settlement or integration in the host country (Beiser and Hou, 2017), but are likely to represent a protective factor in case of the possibility of repatriation. Interventions and psychosocial assessments should take the variation in the role of these factors into account. 
Finally, decision making about the type of interventions to prevent or alleviate psychological distress can be informed by the critical time points identified. Addressing basic needs and accommodation problems may be more important and effective during the first resettlement than embarking in complex psychological or pharmacological interventions. If the immigration status is challenged or revoked, supportive interventions to understand and address concerns and fears about repatriation or to help people plan their return may be provided, particularly if deportation is inevitable (Geraci, 2011). Standard psychiatric interventions may not address these specific concerns and be ineffective, if such fears are a core reason for anxiety or disturbances in mood.

\section{Limitations}

The following limitations need to be acknowledged:

(a) our findings are based on an appraisal of research studies. These studies may not have been able to reach people who face barriers to access mental health services or research teams (Enticott et al., 2017);

(b) the effect of risk and protective factors on rates of mental disorders were not analysed quantitatively using a meta-analysis. Hence we are unable to speculate on which of them has the highest effect on mental health and should be prioritised. However, a meta-analysis of individual risk factors was carried out previously, reporting high heterogeneity and variable methodological quality of the included studies (Steel et al., 2009). In this study, the aim was to identify when risk and protective factors are likely to occur and this can also be of importance for planning treatments and prevention strategies.

(c) a general consideration of risk factors, pooling all mental disorders together, is likely to emphasise risk factors for the most frequently diagnosed disorders (e.g. anxiety and depressive disorders) with less of a focus on the factors associated to disorders with comparatively lower prevalence rates (e.g. psychotic disorders, somatisation disorders, etc.) (Giacco et al., 2018).

(d) low- and middle-income countries were excluded because it was felt that examining the risk and protective factors for mental health in these countries would justify a specific review study. There is an increasing amount of studies exploring the mental health of asylum seekers and refugees in lowand middle-income countries. Twenty-three papers have been written in this area in the last two and a half years and had to be excluded from this review (see Fig. 2). Moreover, in low- and middle-income countries, additional factors might intervene which may complicate the categorisation proposed. A particular issue is that some of these countries can be deemed as 'transit countries'. Migrants expect to only spend some time in transit countries in preparation of reaching the planned final destinations. Recent studies have found high rates of mental disorders in transit countries (Arsenijevic et al., 2017; Vukčević Marković et al., 2017; WHO, 2018) and specific studies are required to understand in detail why this is. Moreover, a difficult financial situation in the host country might make the process of integration of refugees even more difficult and challenging.

\section{Suggestions for future research}

There are a number of unresolved questions in this area, which may be addressed by future research.
All refugees, by definition, have been exposed to stressful events such as political persecution, war and/or torture (UNHCR, 2019). Yet, many of them will not present with diagnosable mental disorders. Future studies should focus on understanding how these individuals are able to show such resilience and use the mechanisms and factors underlying resilience to inform interventions.

With regard to high-income countries, there is a need to better understand the potential selection processes which may occur during migration (WHO, 2018). There may be differences in socio-demographic characteristics among refugees who migrate to high-income countries and those who stay in the home country or migrate to other poorer or nearer countries. Selection processes may also occur between people who stay for a longer time in a given host country and those who leave that country after a shorter period of time.

Finally, understanding the impact of changing social contexts and political climates on the equilibrium between post-migration risk and protective factors may need to be in the research agenda too. Increasing negative (or, on the other hand, positive) social attitudes in host countries may influence the level of discrimination that refugees encounter, the investment in social integration programmes and the opportunities for refugees to flourish. This, in turn, could have a negative impact on asylum seekers' and refugees' mental health. Interventions provided within mental health services may not be able to address these issues on their own.

Acknowledgements. I gratefully acknowledge the help of Miss Maev Conneely-McInerney and Miss Megan Patterson with the editing of this manuscript during its preparation and revision. No other people have actively contributed to the present manuscript. However, I would like to thank the experts involved in the development of technical guidance on 'mental health promotion and mental health care in refugees and migrants' (WHO, 2018). This paper is indebted to the inspiring conversations and the intellectual stimulation received during the meetings of that project. Nevertheless, I should clarify that they did not directly influence the specific design and methodological choices made for this paper and that the opinions and views expressed in this manuscript are purely those of the author.

Financial support. The author did not receive any specific funding for this work.

Conflict of interest. None.

\section{References}

Anderson FM, Hatch SL, Comacchio C and Howard LM (2017) Prevalence and risk of mental disorders in the perinatal period among migrant women: a systematic review and meta-analysis. Archives of Women's Mental Health 20, 449-462.

Arsenijevic J, Schillberg E, Ponthieu A, Malvisi L, Ahmed WAE, Argenziano S, Zamatto F, Burroughs S, Severy N, Hebting C, de Vingne B, Harries AD, Beiser M and Hou F (2017) Predictors of positive mental health among refugees: results from Canada's General Social Survey. Transcultural Psychiatry 54, 675-695.

Ben Farhat J, Blanchet K, Juul Bjertrup P, Veizis A, Perrin C, Coulborn RM, Mayaud P and Cohuet S (2018) Syrian refugees in Greece: experience with violence, mental health status, and access to information during the journey and while in Greece. BMC Medicine 16, 40.

Beiser M and Hou F (2017) Predictors of positive mental health among refugees: Results from Canada's General Social Survey. Transcultural Psychiatry 54, 675-695.

Bogic M, Ajdukovic D, Bremner S, Franciskovic T, Galeazzi GM, Kucukalic A, Lecic-Tosevski D, Morina N, Popovski M, Schützwohl M, Wang D and Priebe S (2012) Factors associated with mental disorders in long-settled war refugees: refugees from the former Yugoslavia in Germany, Italy and the UK. British Journal of Psychiatry 200, 216-223. 
Bogic M, Njoku A and Priebe S (2015) Long-term mental health of warrefugees: a systematic literature review. BMC International Health and Human Rights 15, 29.

Brisset C, Leanza Y, Rosenberg E, Vissandjée B, Kirmayer LJ, Muckle G, Xenocostas S and Laforce H (2014) Language barriers in mental health care: a survey of primary care practitioners. Journal of Immigrant and Minority Health 16, 1238-1246.

Chen W, Hall BJ, Ling L and Renzaho AM (2017a) Pre-migration and postmigration factors associated with mental health in humanitarian migrants in Australia and the moderation effect of post-migration stressors: findings from the first wave data of the BNLA cohort study. The Lancet Psychiatry 4 , 218-229.

Chen W, Ling L and Renzaho AM (2017b) Building a new life in Australia: an analysis of the first wave of the longitudinal study of humanitarian migrants in Australia to assess the association between social integration and selfrated health. BMJ Open 7, e014313.

Dennis CL, Merry L and Gagnon AJ (2017) Postpartum depression risk factors among recent refugee, asylum-seeking, non-refugee immigrant, and Canadian-born women: results from a prospective cohort study. Social Psychiatry and Psychiatric Epidemiology 52, 411-422.

Enticott JC, Shawyer F, Vasi S, Buck K, Cheng IH, Russell G, Kakuma R, Minas H and Meadows G (2017) A systematic review of studies with a representative sample of refugees and asylum seekers living in the community for participation in mental health research. BMC Medical Research Methodology 17, 37.

Euteneuer F and Schäfer SJ (2018) Brief report: subjective social mobility and depressive symptoms in Syrian refugees to Germany. Journal of Immigrant and Minority Health 20, 1533-1536.

Finnvold JE and Ugreninov E (2018). Refugees' admission to mental health institutions in Norway: Is there an ethnic density effect? Social Science and Medicine 209, 43-50.

Geraci D (2011) Facing Return. An Approach for Psychosocial Assistance to (Former) Asylum Seekers and Undocumented Migrants. Utrecht: Pharos (Dutch National Knowledge and Advisory Centre on Migrants and Refugees Health).

Giacco D, Matanov A and Priebe S (2014) Providing mental healthcare to immigrants: current challenges and new strategies. Current Opinion in Psychiatry 27, 282-8.

Giacco D and Priebe S (2018) Mental health care for adult refugees in highincome countries. Epidemiology and Psychiatric Science 27, 109-116.

Giacco D, Laxhman N and Priebe S (2018) Prevalence of and risk factors for mental disorders in refugees. Seminars in Cell and Developmental Biology 77, 144-152.

Gianfreda S (2018) Politicization of the refugee crisis? A content analysis of parliamentary debates in Italy, the $\mathrm{UK}$, and the EU. Italian Political Science Review/Rivista Italiana Di Scienza Politica 48, 85-108.

Hynie M (2018) The social determinants of refugee mental health in the postmigration context: a critical review. Canadian Journal of Psychiatry 63 297-303.

Hvidtfeldt C, Petersen JH and Norredam M (2019) Prolonged periods of waiting for an asylum decision and the risk of psychiatric diagnoses: a 22-year longitudinal cohort study from Denmark. International Journal of Epidemiology 18. pii: dyz091. doi: 10.1093/ije/dyz091. [Epub ahead of print].

Kaltenbach E, Schauer M, Hermenau K, Elbert T and Schalinski I (2018) Course of mental health in refugees-a one year panel survey. Frontiers in Psychiatry 9, 352.

Kapferer S (2003) Cessation of the refugee status. In Cancellation of the Refugee Status, p. 37. Protection Policy and Legal Advice section (PPLA) Department of International Protection United Nations High Commissioner for Refugees (UNHCR): Geneva, Switzerland.

Kartal D, Alkemade N, Eisenbruch M and Kissane D (2018) Traumatic exposure, acculturative stress and cultural orientation: the influence on PTSD, depressive and anxiety symptoms among refugees. Social Psychiatry and Psychiatric Epidemiology 53, 931-941.

Kashyap S, Page AC and Joscelyne A (2019) Post-migration treatment targets associated with reductions in depression and PTSD among survivors of torture seeking asylum in the USA. Psychiatry Research 271, 565-572.
Le L, Morina N, Schnyder U, Schick M, Bryant RA and Nickerson A (2018) The effects of perceived torture controllability on symptom severity of posttraumatic stress, depression and anger in refugees and asylum seekers: a path analysis. Psychiatry Research 264, 143-150.

Lee Y, Lee M and Park S (2017) Mental health status of North Korean refugees in South Korea and risk and protective factors: a 10-year review of the literature. European Journal of Psychotraumatology 8, 1-13.

Leiler A, Bjärtå A, Ekdahl J and Wasteson E (2019) Mental health and quality of life among asylum seekers and refugees living in refugee housing facilities in Sweden. Social Psychiatry and Psychiatric Epidemiology 54, 543-551.

Lewis-Fernández R and Aggarwal NK (2013) Culture and psychiatric diagnosis. Advances in Psychosomatic Medicine 33, 15-30.

Lindencrona F, Ekblad S and Hauff E (2008) Mental health of recently resettled refugees from the Middle East in Sweden: the impact of preresettlement trauma, resettlement stress and capacity to handle stress. Social Psychiatry and Psychiatric Epidemiology 43, 121-131.

Miller KE and Rasmussen A (2017) The mental health of civilians displaced by armed conflict: an ecological model of refugee distress. Epidemiology and Psychiatric Science 26, 129-138.

Miller A, Hess JM, Bybee D and Goodkind JR (2018) Understanding the mental health consequences of family separation for refugees: implications for policy and practice. American Journal of Orthopsychiatry 88, 26-37.

Müller MJ, Zink S and Koch E (2018) The negative impact of an uncertain residence status: analysis of migration-related stressors in outpatients with Turkish migration background and psychiatric disorders in Germany over a 10-year period (2005-2014). Journal of Immigrant and Minority Health 20, 317-326.

Mulugeta W, Xue H, Glick M, Min J, Noe MF and Wang Y (2019) Burden of mental illness and non-communicable diseases and risk factors for mental illness among refugees in Buffalo, NY, 2004-2014. Journal of Racial and Ethnic Health Disparities 6, 56-63.

Myhrvold T and Småstuen MC (2017) The mental healthcare needs of undocumented migrants: an exploratory analysis of psychological distress and living conditions among undocumented migrants in Norway. Journal of Clinical Nursing 26, 825-839.

Nickerson A, Schick M, Schnyder U, Bryant RA and Morina N (2017) Comorbidity of posttraumatic stress disorder and depression in tortured, treatment-seeking refugees. Journal of Traumatic Stress 30, 409-415.

Nosè M, Turrini G, Imoli M, Ballette F, Ostuzzi G, Cucchi F, Padoan C, Ruggeri M and Barbui C (2018) Prevalence and correlates of psychological distress and psychiatric disorders in asylum seekers and refugees resettled in an Italian catchment area. Journal of Immigrant and Minority Health 20, 263-270.

Ottisova L, Hemmings S, Howard LM, Zimmerman C and Oram S (2016) Prevalence and risk of violence and the mental, physical and sexual health problems associated with human trafficking: an updated systematic review. Epidemiology and Psychiatric Science 25, 317-341.

Park S, Lee Y and Jun JY (2018) Trauma and depression among North Korean refugees: the mediating effect of negative cognition. International Journal of Environmental Research and Public Health 15, pii: E591.

Poole DN, Hedt-Gauthier B, Liao S, Raymond NA and Barnighausen T (2018) Major depressive disorder prevalence and risk factors among Syrian asylum seekers in Greece. BMC Public Health 18, 908.

Priebe S, Giacco D and El-Nagib R (2016) Public Health Aspects of Mental Health Among Migrants and Refugees: A Review of the Evidence on Mental Health Care for Refugees, Asylum Seekers and Irregular Migrants in the WHO European Region [Internet]. Copenhagen: WHO Regional Office for Europe.

Rees SJ, Fisher JR, Steel Z, Mohsin M, Nadar N, Moussa B, Hassoun F, Yousif M, Krishna Y, Khalil B, Mugo J, Tay AK, Klein L and Silove D (2019) Prevalence and risk factors of major depressive disorder among women at public antenatal clinics from refugee, conflict-affected, and Australian-born backgrounds. JAMA Network Open 2, e193442.

Sangalang CC, Becerra D, Mitchell FM, Lechuga-Peña S, Lopez K and Kim I (2018) Trauma, post-migration stress, and mental health: a comparative analysis of refugees and immigrants in the United States. Journal of Immigrant and Minority Health 21, 909-919. 
Schick M, Morina N, Mistridis P, Schnyder U, Bryant RA and Nickerson A (2018) Changes in post-migration living difficulties predict treatment outcome in traumatized refugees. Frontiers in Psychiatry 9, 476.

Schweitzer RD, Vromans L, Brough M, Asic-Kobe M, Correa-Velez I, Murray K and Lenette C (2018) Recently resettled refugee women-at-risk in Australia evidence high levels of psychiatric symptoms: individual, trauma and post-migration factors predict outcomes. BMC Medicine 16, 1.

Song SJ, Subica A, Kaplan C, Tol W and De Jong J (2018) Predicting the mental health and functioning of torture survivors. Journal of Nervous and Mental Disease 206, 33-37.

Steel Z, Chey T, Silove D, Marnane C, Bryant RA and van Ommeren M (2009) Association of torture and other potentially traumatic events with mental health outcomes among populations exposed to mass conflict and displacement: a systematic review and meta-analysis. JAMA 302, 537-549.

Tinghög P, Malm A, Arwidson C, Sigvardsdotter E, Lundin A and Saboonchi F (2017) Prevalence of mental ill health, traumas and postmigration stress among refugees from Syria resettled in Sweden after 2011: a population-based survey. BMJ Open 7, 12.
Turrini G, Purgato M, Ballette F, Nosè M, Ostuzzi G and Barbui C (2017) Common mental disorders in asylum seekers and refugees: umbrella review of prevalence and intervention studies. International Journal of Mental Health Systems 11, 51.

United Nations High Commissioner for Refugees (2019) Who is a refugee? Available at https://www.unrefugees.org/refugee-facts/what-is-a-refugee/ (Accessed 19 March 2019).

Vukčević Marković M, Gašić J and Bjekić J (2017) Refugees' Mental Health. Belgrade: Psychosocial Innovation Network. Available at http://psychosocialinnovation.net/wp-content/uploads/2017/11/Refugees_Mental_Health_2017_ research_report.pdf (Accessed 31 August 2018).

WHO Regional Office for Europe (2018) Mental Health Promotion and Mental Health Care in Refugees and Migrants (Technical Guidance on Refugee and Migrant Health). Copenhagen: WHO Regional Office for Europe.

Yang MS and Mutchler JE (2019) The high prevalence of depressive symptoms and its correlates with older Hmong refugees in the United States. Journal of Aging and Health, doi: 10.1177/0898264319844088. (Accessed 19 April 2019). [Epub ahead of print]. 